\title{
The Impact of Lectures (Given to Children from 9-11 Years) on the Recognition of Risk Situations for the Occurrence of Traumatic Brain Injury
}

\section{O impacto de aulas expositivas (ministradas para crianças de 9 a 11 anos) sobre o reconhecimento de situações de risco para ocorrência de traumatismo crânioencefálico}

\author{
Victor Frandoloso ${ }^{1}$ Felipe T. da Silva ${ }^{1}$ Camilla Donida Magnabosco ${ }^{1}$ \\ 1 Universidade do Planalto Catarinense, Lages, SC, Brazil \\ Arq Bras Neurocir 2018;37:95-100. \\ Address for correspondence Victor Frandoloso, Medical Student, Rua \\ Fernando Ataíde, 811, Bairro Sagrado Coração de Jesus, CEP: 88508- \\ 120, Lages, SC, Brazil (e-mail: victfrandoloso@gmail.com).
}

\begin{abstract}
Introduction It is believed that the prevention of head trauma (TBI) can be achieved with campaigns to raise awareness about safety measures.

Methods Longitudinal, observational and analytical cohort study. Standardized questionnaires were administered to students from 4th to 6th grade elementary school, before and immediately after the intervention. Items on habits//exposure to TCEs were analyzed categorically as theoretical knowledge were evaluated semicontinuously. A randomly selected subgroup was subjected to the same questionnaires past 9 months of educational lectures.

Results A total of 117 students (55 girls) were interviewed initially (4th [ $n 1 / 414 / 117]$, 5th $\left[n \frac{1}{4} 54 / 117\right]$ and 6 th $\left[n \frac{1}{4} 49 / 117\right]$ series, average age of $9.8,10,7$ and 11.8 years). Of these, 22 students were submitted to the late posttest (7th grade, 12.7 years on average). Among the participants, 37\% (43/116) students had already suffered/knew someone who suffered TBI, 58\% (18/31) were involved in traffic accidents and 42\% (13/ 31) were involved in accidents with bicycle, skates or skateboard. Among these subjects, $90.3 \%$ reported occasional use or never having used protection during play. A significant discrepancy was detected between safety habits and theoretical knowledge related to helmet use and the use of seat belts (effective use versus hits on knowledge of respectively $37 \%$ versus $61 \%$, and $70 \%$ versus $92 \%$ ). In the theoretical evaluation, improvement was observed only with regard to the importance of helmet usage ( $61 \%$ in the pretest, $72 \%$ in the immediate posttest and $95 \%$ in the late posttest). Conclusion The high rate of experience with TBI coupled with the significant discrepancy between habits and knowledge regarding trauma prevention stress the

Keywords

- trauma

- accidents

- prevention need for effective measures leading to their actual implementation. The intervention increased awareness about the importance of helmet usage, suggesting partial effectivity from a theoretical standpoint.
\end{abstract}

received

July 24, 2015

accepted

October 21, 2015

published online

February 4, 2016
DOI https://doi.org/

10.1055/s-0035-1570363. ISSN 0103-5355.
Copyright $(2018$ by Thieme Revinter

Publicações Ltda, Rio de Janeiro, Brazil
License terms

c) $\oplus \triangleq \$$ 


\section{Resumo}

\section{Palavras-chave}

- trauma

- acidentes

- prevenção
Introdução Acredita-se que a prevenção de traumatismo cranioencefálico (TCE) possa ser alcançada com campanhas de conscientização sobre medidas de segurança. Métodos Estudo de coorte, longitudinal, observacional e analítico. Questionários padronizados foram aplicados a estudantes da quarta a sexta série do primeiro grau, antes e imediatamente após a intervenção. Itens sobre hábitos e/ou exposição a TCE foram analisados categoricamente, enquanto conhecimentos teóricos foram avaliados semicontinuamente. Um subgrupo escolhido aleatoriamente foi submetido aos mesmos questionários depois de 9 meses das palestras educacionais.

Resultados Um total de 117 alunos (55 meninas) foram entrevistados inicialmente (4a [n 1/4 14/117], 5a [n 1/4 54/117] e $6^{a}$ [ $n$ 1/4 49/117] séries, com média de idades de 9,8; 10,7; e 11,8 anos, respectivamente). Destes, 22 alunos foram submetidos ao pós-teste tardio (7a série, 12,7 anos em média). Dos alunos que responderam ao questionário, $37 \%$ (43/116) já tinham sofrido e/ou conheciam alguém que sofreu TCE; 58\% (18/31) se envolveram em acidentes de trânsito; e 42\% (13/31) em acidentes com bicicleta, patins ou skate. Destes, $90,3 \%$ fizeram uso eventual ou nunca fizeram uso de proteção durante atividades lúdicas. Foi detectada discrepância significativa entre hábitos de segurança e conhecimento teórico referente ao uso de capacete e cinto de segurança (uso efetivo versus acertos sobre conhecimento de, respectivamente, $37 \%$ versus $61 \%$ e $70 \%$ versus $92 \%)$. Na avaliação teórica, houve melhora significativa apenas no quesito sobre a importância do uso de capacete ( $61 \%$ no pré-teste, $72 \%$ no pós-teste imediato e $95 \%$ no pós-teste tardio).

Conclusão A alta taxa de experiências com TCE somada à significativa discrepância entre hábitos e conhecimentos para evitar traumas salienta a necessidade de implementação de medidas efetivas. A intervenção permitiu aumentar a percepção sobre a importância do uso de capacete, sugerindo efetividade do ponto de vista teórico.

\section{Introduction}

The aim of trauma prevention programs is to provide a transformation in the knowledge, attitude and behavior of a previously identified segment of society. Offering information to potential victims is not enough to prevent trauma. A program must be implemented to influence the attitude of society, and more importantly, change its behavior. ${ }^{1-3}$

Trauma is now one of the main causes of child morbidity and mortality in developed countries and also in Brazil, where it already has a prominent place in statistics. ${ }^{4}$ The best way to fight the disease, the trauma and its consequences is through accident prevention. Although falls are almost impossible to be prevented, there are practical and basic norms that are universally useful. On the other hand, the incidence of other accidents, such as slab falls, washing tank syndrome and traffic accidents can be minimized through awareness campaigns organized by specialty societies and performed jointly with the public authorities. ${ }^{4,5}$

Several attempts have failed to pursue the ideal teaching methodology for an accident prevention program that actually causes changes in behavior. The literature shows that it is challenging to find the reasons why it is so difficult to change young people's attitudes toward injury prevention.

Based on these premises and adapting to the American educational model Think First, which aims to avoid injuries to the brain, spinal cord and other traumatic injuries, the Socie- dade Brasileira de Neurocirurgia (Brazilian Society of Neurosurgery, SBN, in the Portuguese acronym) started in 1995 the educational project Pense Bem ("Think Well") for the prevention of traumatic brain injury (TBI). The project aims to expand knowledge in the area of primary prevention of TBI and reduce the severity of traumas, especially among children aged 10 to 14 years in elementary/middle school. To this end, videos, CDs, stickers, banners and educational brochures have been created. ${ }^{6}$

The SBN's Pense Bem project addresses the importance of preventing brain injury. The goal is to raise awareness among students (aged between 9 and 11 years) regarding the identification of risk situations for the occurrence of TBI. The application of a standardized questionnaire (research instrument) aims to estimate the impact of this educational intervention immediately after its application and in the medium term. By using these data, it will be possible to approach the school environment in public institutions of the municipality of Lages, SC, to evaluate the understanding of children between 9 and 11 years old regarding risk situations for the occurrence of TBI.

\section{Material and Methods}

Observational, analytical and longitudinal study, analyzing a cohort initially sampled for convenience. Sampling for the late posttest was performed using a randomly selected subgroup of the initial cohort. 
The educational intervention was performed together with the project "Pense Bem: Prevention of Traumatic Brain Injury in Children." The classes were performed following a standard protocol, once in each class, lasting 10 minutes. The standardized questionnaire was applied at two moments to all enrolled students: pretest and immediate posttest (that is, shortly after the intervention). Subsequently, one class was randomly selected for the late posttest (that is, 9 months postintervention) (-Fig. 1).

A statistical analysis for comparing the correctness rates between pre and posttest, as well as the composition of the groups in terms of gender, was performed by applying the Kappa test for paired samples. The comparison between the results of the immediate and late posttests was performed with the Fisher exact test for independent samples. The level of significance was preestablished at 0.05 . The analyzes were performed using the BioEstat 5.3 software (Instituto de Desenvolvimento Sustentável Mamirauá, Tefé, AM, Brazil).

\section{Results}

In all, 117 students answered the pretest; 55 of whom were girls. Students of the $4^{\text {th }}, 5^{\text {th }}$ and $6^{\text {th }}$ grades of elementary/middle school (mean age of 9.8, 10.7 and 11.8 years, respectively) were interviewed. Regarding the distribution, the subjects were predominantly in the $6^{\text {th }}$ (n $1 / 449 / 117$ ) and $5^{\text {th }}$ grades (n $1 / 4$ 54/117), and fewer in the $4^{\text {th }}$ grade (n $1 / 414 / 117$ ) (-Table 1 ).

Among the students, 37\% (43/116) had already suffered or knew someone who had suffered some type of TBI. Of these, 58\% (18/31) were involved in traffic accidents; and $42 \%$ $(13 / 31)$ in bicycle accidents, skating or skateboarding. Six cases were reported to have suffered falls, two suffered TBI from soccer, two from hammer strikes, two from stone strikes and two from fights (-Table 2 ).

In the late posttest, applied 9 months later to a random sample (for convenience) obtained from the initial sample, students answered the questions correctly, as seen in - Table 3.

Among the items investigating theoretical knowledge, scores close to $90-100 \%$ were observed in questions 1 to 3 (see attached questionnaire). On the other hand, the item referring to the use of helmet (4) showed an improvement in the score, both between pretest and immediate posttest, as well as between immediate and late posttests (-Table 3 ).

Regarding the change in habits between pretest and late posttest, an increase in the percentage of students reporting seat belt use was observed. The other habits did not show a

School:

Grade: Date of Birth: Gender: M ( ) F ( )

1) Do you ride a bike, skate or skateboard?

YES ( ) NO ( )

2) If yes, do you wear any protective gear (helmet, knee pads, elbow pads) when riding?

ALWAYS ( ) SOMETIMES ( ) NEVER ( )

3) Do you usually ride in a car?

YES ( ) NO ( )

4) When you ride in a car, how often do you wear a seat belt? ALWAYS ( ) SOMETIMES ( ) NEVER ( )

5) Have you ever ridden with drivers who had consumed alcohol? ALWAYS ( ) SOMETIMES ( ) NEVER ( )

6) Have you, a family member or anyone you know ever had a head injury (head banging followed by vomiting, fainting, or severe pain)?

YES ( ) NO ( )

7) Did you or the person see a doctor?

YES ( ) NO ( )

How was you/the person injured?

a) Diving.

b) Traffic accident.

c) Bicycle/skating/skateboarding accident.

d) Other. Which?

Fig. 1 Questionnaire applied. 
Table 1 Population characteristics

\begin{tabular}{|l|l|l|l|l|}
\hline School & \multirow{2}{*}{ Grade } & \multirow{2}{*}{ Age } & \multicolumn{2}{|l|}{ Gender } \\
\cline { 4 - 5 } & & & Male & Female \\
\hline CAIC NSP & $4^{\text {th }}(14$ students $)$ & 9.8 years & 5 & 9 \\
\hline CAIC NSP & $5^{\text {th }}(29$ students $)$ & 10.7 years & 18 & 11 \\
\hline CAIC NSP & $6^{\text {th }}(32$ students $)$ & 11.5 years & 14 & 18 \\
\hline CAIC ID & $5^{\text {th }}(25$ students $)$ & 10.7 years & 13 & 12 \\
\hline CAIC ID & $6^{\text {th }}(17$ students $)$ & 12.1 years & 12 & 5 \\
\hline Total & 117 students & 10.9 years & 62 & 55 \\
\hline
\end{tabular}

Abbreviations: CAIC ID, Centro de Atenção Integral à Criança e ao Adolescente Irmã Dulce (Center for Integral Attention to Children and Adolescents Sister Dulce); CAIC NSP, Centro de Atenção Integral à Criança e ao Adolescente Nossa Senhora dos Prazeres (Center for Integral Attention to Children and Adolescents Nossa Senhora dos Prazeres).

Table 2 Previous experiences with traumatic brain injury

\begin{tabular}{|l|l|l|l|}
\hline & TBI $^{\mathbf{a}}$ & $\begin{array}{l}\text { Medical } \\
\text { assistance }\end{array}$ & $\begin{array}{l}\text { How was the } \\
\text { person injured? }\end{array}$ \\
\hline Yes & $37 \%$ & $89 \%$ & \\
\hline No & $63 \%$ & $11 \%$ & \\
\hline Diving & & & $0 \%$ \\
\hline Traffic accidents & & & $58 \%$ \\
\hline $\begin{array}{l}\text { Cycling, skating or } \\
\text { skateboarding } \\
\text { accidents }\end{array}$ & & & $42 \%$ \\
\hline $\begin{array}{l}\text { Other. Which? } \\
\text { (n) }\end{array}$ & & & $\begin{array}{l}\text { Fall, soccer, } \\
\text { hammer, stone, } \\
\text { fight. }\end{array}$ \\
\hline
\end{tabular}

Abbreviations: TBI, traumatic brain injury.

Notes: aHave you, a family member or anyone you know ever had a head injury (head banging followed by vomiting, fainting, or severe pain)?

${ }^{\mathrm{b}}$ Did you or the person see a doctor? (Pretest questionnaire, Annex B).

Table 3 Distribution of responses in the immediate and late posttests according to each alternative

\begin{tabular}{|l|l|l|l|}
\hline Correct responses & Pretest & $\begin{array}{l}\text { Immediate } \\
\text { posttest }\end{array}$ & $\begin{array}{l}\text { Late } \\
\text { posttest }\end{array}$ \\
\hline $\begin{array}{l}\text { Traffic-automobile } \\
\text { (seat belt use) }\end{array}$ & $93.2 \%$ & $93 \%$ & $100 \%$ \\
\hline $\begin{array}{l}\text { Traffic-pedestrians } \\
\text { (using crosswalk) }\end{array}$ & $88 \%$ & $89 \%$ & $100 \%$ \\
\hline $\begin{array}{l}\text { Domestic } \\
\text { (oven, stairs or couch) }\end{array}$ & $89 \%$ & $91 \%$ & $95 \%$ \\
\hline $\begin{array}{l}\text { Sports } \\
\text { (helmet use) }\end{array}$ & $61 \%$ & $72 \%^{\#^{*}}$ & $95 \%^{\#}$ \\
\hline
\end{tabular}

Notes: ${ }^{*} p<0.05 ;{ }^{*}$ Kappa test; \# Fisher exact test.
Table 4 Habits of the participants in terms of use of safety equipment

\begin{tabular}{|l|l|l|}
\hline Habits & Preintervention & Postintervention \\
\hline $\begin{array}{l}\text { Leisure activities } \\
\text { (cycling, skating, } \\
\text { or skateboarding) }\end{array}$ & $76 \%(89 / 117)$ & $79 \%(19 / 24)$ \\
\hline $\begin{array}{l}\text { Use of personal } \\
\text { protective equipment }\end{array}$ & $37 \%(39 / 106)$ & $47 \%(9 / 19)$ \\
\hline Use of automobile & $91 \%(106 / 117)$ & $96 \%(23 / 24)$ \\
\hline Seat belt use & $70 \%(81 / 117)$ & $91 \%{ }^{*}(22 / 24)$ \\
\hline $\begin{array}{l}\text { Driving under the } \\
\text { influence of alcohol }\end{array}$ & $11 \%(13 / 117)$ & $4 \%(1 / 24)$ \\
\hline
\end{tabular}

Note: ${ }^{*} p<0.05$, Kappa test for independent samples.

significant increase in the effective implementation of security measures. Nevertheless, there is a tendency, albeit spurious, for an increase in the use of personal protective equipment (PPE) and a reduction in drivers under the influence of alcohol ( - Table 4 ).

\section{Discussion}

The extension project "Pense Bem: Prevention of Traumatic Brain Injury in Children" was applied to children from fourth to sixth grades. Like other trauma prevention programs, it aims to provide a transformation in the knowledge, attitude and behavior of a previously identified segment of society. Simply offering information to potential victims is not enough to prevent trauma. A program must be implemented to influence the attitude of society and, more importantly, to change its behavior. ${ }^{1}$

Salvarani ${ }^{2}$ conducted an intervention program based on the Pense Bem project in Maringá, Paraná, Brazil. The program sought the participation of public agencies and private institutions to establish a network of information facilitators and multipliers, and to reduce the absolute number and severity of TBI in the municipality. For this, educational handouts were distributed, and lectures and videos were presented. After the intervention was completed, the results did not indicate an absolute decrease in the number of traffic accidents and victims. The impact of the program was verified by the reduction of the trauma severity in these victims. Besides the decrease in mortality in $27.2 \%$, there was a decrease in the severity of trauma in general, and in the number of cases and severity of TBI.

Falavigna et $\mathrm{al}^{7,8}$ performed two interventional studies based on the Pense Bem project in Caxias do Sul, Rio Grande do Sul, Brazil. In 2012, their randomized study used 1,049 high school students, with application of pretest, immediate and short-term posttests. The attitude toward injury prevention did not show any change in the population. In 2014, the researchers opted for a randomized, eight-step study using educational interventions from different society groups and targeting fifth graders and sophomores in public and private schools. Their work did not modify most of the attitudes toward injury prevention. 
Neither Falavigna et $\mathrm{al}^{7,8}$ nor Salvarani ${ }^{2}$ obtained the expected results in their studies. These authors pointed out that it is a challenge to find out why it is so difficult to change young people's attitudes toward injury prevention. On the other hand, the questionnaire employed, as well as the educational interventions, were performed in a complex way. For example, the questionnaire contained questions about neuroanatomy, an unnecessary knowledge in the prevention of TBI.

This study investigated the degree of change in the pattern of responses to standardized questionnaire (pretest, immediate and late posttests). The questionnaire (in the annex) was formulated in simple language, with easy theoretical questions and answer options, short and compatible with the comprehension of students in the researched age group. Questions about habits, however, were formulated differently. Those included categorical and closed answers, to conceal the possible connection between habits and theoretical knowledge. This measure was taken to exclude the eventual possibility of students trying to "guess" the answers in the two different segments of the questionnaire. Likewise, habits were questioned 9 months apart and without prior notice, so as to reduce the memory bias. Following this method, an improvement in the number of correct answers for question 4 of the segment (use of helmet) on theoretical knowledge was observed. The scores rose from 61 to $72 \%$ and finally reached $93 \%$ in the pretest, immediate and late posttests, respectively. On the other hand, questions 1 to 3 showed high rates of right answers, very close to $100 \%$. This homogeneous and correct pattern suggests that the previous measures seem obvious.

In relation to the comparison between security measures and theoretical knowledge, a disconnection of extreme importance was observed. When asked about their habits, $90 \%$ of students did not wear any protection on a regular basis. This finding supports the theory that the students did not realize the connection between the portions of theory and the habits of the questionnaire. In addition, the increase in theoretical correctness rates suggests an effectiveness of the intervention in making students aware of the importance of using helmets.

Activities with potential risk of progressing to TBI were considered in the study. Leisure activities (cycling, skating, skateboarding), as well as the use of motor vehicles, can more easily result in TBI in cases of disobedience of safety standards. The degree of exposure to risk in leisure and locomotion activities were respectively 76 and $91 \%$. Thus, a high degree of vulnerability was observed in the studied population.

Silveira ${ }^{9}$ tried to know needs of the TBI children care and, using an integrative review, found predominance of preschool and school-age male victims, automobile accidents, and falls (including leisure activities). Considering that $90 \%$ of the children reported engaging in activities without protective measures (helmet), intervention in this aspect sounds promising, especially because it is a cost-effective measure. In comparison, $57 \%$ of respondents used cars in situations of potential risk, reinforcing the need to supplement knowledge in both areas, perhaps with more emphasis on leisure activities. That is partially due to the passiveness of students, being passengers in those situations. Thus, the most appropriate targets for campaigns in the case of automobiles would be adults. Since the child, when playing, is often the main actor (often in the absence of adults), it crucial to emphasize the safety aspects of helmet use.

When identifying the main external causes among children under 15 in outpatient and inpatient settings and death, Martins and Andrade ${ }^{10}$ established that head and neck correspond to the most affected regions of the body.

Among general injuries, TBI corresponded to $34.7 \%$ of emergency room visits, $37.4 \%$ of hospitalizations and $50 \%$ of deaths.

In our study, another interesting finding relates to the experiences of TBI respondents. Of the $37 \%$ who responded positively to this question, $58 \%$ reported an automobile accident (versus $42 \%$ with bicycles). In addition, $89 \%$ of those who reported TBI needed medical care, pointing to the severity of these events. Considering that adults should be thoroughly oriented about the use of the seat belt and the non-use of alcohol at the wheel, we can make a reciprocal consideration, that is, children could act as vectors for changing attitudes within the family. The use of helmets and the care taken at the wheel were therefore equally important in terms of damages.

Nevertheless, there was an improvement only regarding seat belt use. However, some improvement, although not significant, could be observed in the indicators referring to other safety habits. Therefore, future studies may better elucidate ways to effectively change habits for TBI prevention.

The present study also presents limitations. The initially stipulated sample size, as well as the sampling strategy could not be met. This happened due to abnormal weather conditions (hail) that affected the normal activities of public schools during the period when the lectures were to be given and data were to be collected. Thus, sampling was not representative of the students' population of the municipality of Lages as a whole, affecting the generalization of the results (external validity of the study). In addition, the power of applied statistical tests (and therefore the chance of incurring type one error) were compromised. Although the choice of the subgroup undergoing the late posttest was initially random, it can be ascertained that the group had more mature students than the sample submitted to the initial phase of the study (chance of incurring type 2 error). In addition, the time elapsed between the initial intervention and the delayed intervention may have led, per se, to an improvement in the rate of correctness, since the students matured during this period. This may affect the internal validity of the results, since it generates selection bias, limiting the power of the applied statistical test.

Nevertheless, within the limitations listed here, all possible efforts were made to comply with the protocol initially proposed.

\section{Conclusion}

The high rate of experiences with TBI added to the significant discrepancy between habits and knowledge to avoid trauma, emphasizing the need to implement effective measures for its prevention. The intervention allowed to increase the 
100 The Impact of Lectures (Given to Children from 9-11 Years) Frandoloso et al.

perception about the importance of the use of helmet, suggesting effectiveness from the theoretical point of view. The present study presents important limitations imposed by logistical issues. Nevertheless, all possible measures were taken to get close to the originally proposed protocol.

\section{Final Notes}

This study was supported by the Brazilian National Council for Scientific and Technological Development (CNPq, in the Portuguese acronym), within the framework of the Institutional Scholarship Program of Scientific Initiation (Programa Institucional de Bolsas de Iniciação Científica PIBIC, in the Portuguese acronym) 2014/2015.

\section{Acknowledgments}

To the Secretary of Education of the Municipality of Lages, Marimília Casa Costa Coelho. To the Academics and Professors of the Medicine School of Universidade do Planalto Catarinense, participants of the Extension Project Pense Bem and to Sociedade Brasileira de Neurocirurgia (Brazilian Society of Neurosurgery).

\section{References}

1 NAEMT. Atendimento pré-hospitalar ao traumatizado - PHTLS; [translated by Renata Scavone et al.] 7.ed. Rio de janeiro: Elsevier; 2011
2 Salvarani CP. Impacto de um projeto de intervenção de acidentes de trânsito em um município no interior do Brasil [thesis]. Faculdade de Medicina de Ribeirão Preto/USP, 2006

3 Greene A, Barnett P, Crossen J, Sexton G, Ruzicka P, Neuwelt E. Evaluation of the THINK FIRST For KIDS injury prevention curriculum for primary students. Inj Prev 2002;8(03):257-258

4 Lopez FA, Júnior DC. Tratado de pediatria: sociedade brasileira de pediatria. 2.ed. Barueri, SP: Manole; 2012

5 Farage L, Colares VS, Capp Neto M, Moraes MC, Barbosa MC, Branco JdeA Jr. As medidas de segurança no trânsito e a morbimortalidade intra-hospitalar por traumatismo craniencefálico no Distrito Federal. Rev Assoc Med Bras (1992) 2002;48(02):163-166

6 Brasileira de Neurocirurgia S. (SBN). See: http://www.sbn.com. br/index/institucional/pense-bem Last access: 26 de abr. 2014

7 Falavigna A, Teles AR, Velho MC, et al. Impact of an injury prevention program on teenagers' knowledge and attitudes: results of the Pense Bem-Caxias do Sul Project. J Neurosurg Pediatr 2012;9(05):562-568

8 Falavigna A, Medeiros GS, Canabarro CT, et al. How can we teach them about neurotrauma prevention? Prospective and randomized "Pense Bem-Caxias do Sul" study with multiple interventions in preteens and adolescents. J Neurosurg Pediatr 2014;14 (01):94-100

9 Silveira AG. Trauma cranioencefálico na criança: uma revisão integrativa. Trabalho de conclusão de curso da escola de enfermagem da Universidade federal do Rio Grande do Sul, Porto Alegre, 2013

10 Martins CBG, Andrade SM. Causas externas entre menores de 15 anos em cidade do sul do Brasil: atendimentos em pronto-socorro, internações e óbitos. Rev Bras Epidemiol 2005;8(02):194-204 